\title{
A Study of Probable Reasons for Saudi Learners' Weakness in Listening Comprehension
}

\author{
Sultan Samah A Almjlad ${ }^{1}$ \\ ${ }^{1}$ Department of English Language, Northern Borders University, Arar, Saudi Arabia \\ Correspondence: Sultan Samah A Almjlad, Department of English Language, Northern Borders University, Arar, \\ Saudi Arabia. E-mail: ssaj2014@hotmail.com
}

\author{
Received: February 15, 2017 Accepted: April 19, 2017 Online Published: July 15, 2017 \\ doi:10.5539/ijel.v7n4p166 URL: http://doi.org/10.5539/ijel.v7n4p166
}

\begin{abstract}
This study investigates the listening comprehension problems of Saudi students. Forty Saudi postgraduate students from both genders (24 males and 16 females) participated in the study and all participants were postgraduate students at the University of Essex in the UK. The questionnaire was the only instrument used to collect data. The main findings of the study discovered were related to listeners first. Secondly, the study showed a significant difference between the academic lectures or seminars in five problems related to both listener and text, while thirdly the study showed a non-significant difference between the Saudi male and female students in terms of listening comprehension. Fourthly, the study discovered that the LC problems vary based on the learners' academic levels as the LC problems get fewer when the academic level gets higher, confirming negative correlations between academic level and LC problems. After applying aggression analysis on some variables, the study also demonstrated that the length of studying English has a remarkable effect on the LC for Saudi students.
\end{abstract}

Keywords: listening comprehension, problems, academic, casual, most, correlation

\section{Introduction}

Listening skills are considered as critical dimension in language learning and the most significant communication skill in people's lives. Moreover, listening is considered essential in terms of second language acquisition according to Rost (2011), who mentioned that "a key difference between more successful and less successful acquirers relates in large part to their ability to use listening as a means of acquisition” (p. 94). Therefore, the significance of listening cannot be ignored as the first step towards language learning and acquisition. Despite this, it is still considered as one of the least developed and understood processes among language learners.

Morley (2001) mentioned that listening received special attention within instructional frameworks during the 1980s. However, in the 1990s, the importance of listening increased drastically as one of the most important skills in language instruction; presently, listening comprehension is considered as significant aspect of language learning. However, "much of work remains to be done in both theory and practice" (Morley, 2001, p. 69). Conway (1982) argued that poor listening skills are considered as a main reason for the failure of university students as these problems make communication difficult.

From his experience in EFL teaching, the researcher noticed that the Saudi learners were unable to score good marks in listening tests including IELTS sub section listening examination. Moreover, the learners sometimes cannot understand what is said in academic settings and casual conversations with native speakers, which means that the Saudi learners of English find it hard to comprehend what they hear. Thus, the researcher has dedicated this study to exploring the issues related to LC such as the most frequent problems among Saudi learners in two communication settings, in addition to identifying the real reasons which prevent Saudi EFL learners' from accessing good solutions which could remedy this problem. Moreover, the effect of some variables on listening comprehension is also explored.

\subsection{Importance of Listening for the Language Learner}

Listening skills were neglected at the beginning of the 1970s. However, as mentioned before the importance of listening increased enormously during the 1990s as a vital skill in language teaching (Morley, 2001). Kemp 
(2010) referred to the importance of listening in people's daily lives, indicating that people spend a great deal of time listening in different situations. Moreover, Krashen (1985) highlighted the importance of listening by describing that people acquire language through listening to the linguistic information. Dunkel (1986) emphasized the importance of listening comprehension in developing the capabilities of the learners in speaking as he asserted that improving the capabilities of the learners in listening comprehension will be directly reflected in their speaking abilities. Many studies have demonstrated that approximately 70 to $80 \%$ of life is considered communication, while about $45 \%$ is listening, $30 \%$ is speaking, $16 \%$ is reading and $9 \%$ is writing (Ward, 1990; Feyten, 1991). Furthermore, Werner (1975) conducted an investigation into the importance of listening as one form of communication for school and college students, homemakers and a number of workers in several of other occupations; the results demonstrated that they spend about $55 \%$ of their spent time listening, $13 \%$ reading, $8 \%$ writing.

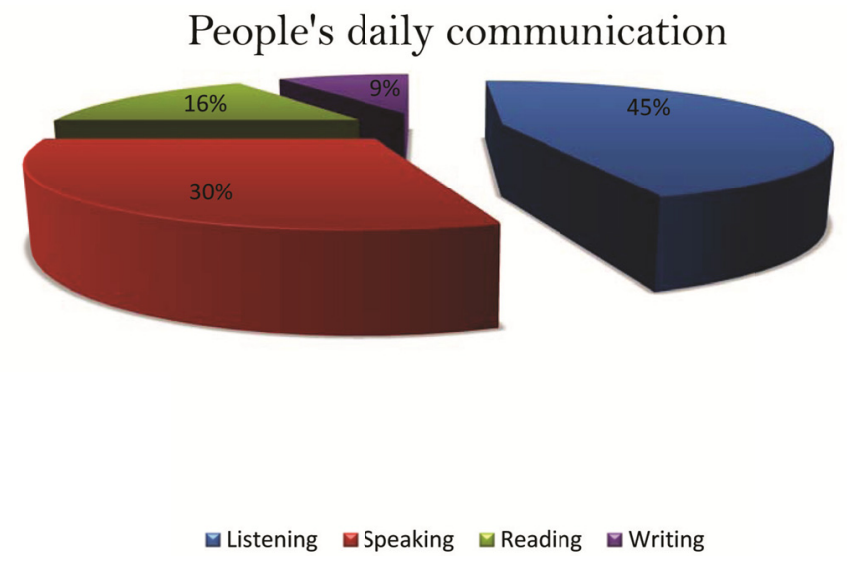

Figure 1. Proportions of time spent by people in daily communication

\subsection{Definition of Terms}

\subsubsection{Listening}

Many researchers have provided different definitions of listening. Lundsteen (1971) described it as a process in which a spoken language is transformed into a meaningful input in listeners' minds. Morley (1972) indicated listening includes auditory discrimination, aural grammar, selecting necessary information, remembering it, and connecting it to the process between sound and form of meaning. In addition, Purdy (1997) defined listening as "the active and dynamic process of attending, perceiving, interpreting, remembering, and responding to the expressed (verbal and nonverbal), needs, concerns, and information, and information offered by human beings" (p. 8). Lastly, Rost (2002) defined listening as a complex process of interpretation in which listeners' match what they hear with what they already know.

\subsubsection{Listening Comprehension}

The term "listening comprehension" has also been defined by different authors. For example, Rost (1990, p. 33) defined listening comprehension as "essentially an inferential process based on a perception of cues rather than a straightforward matching of sound to meaning", while Hasan (2000) defined it as a process which includes meaningful interactivity and understanding regarding spoken language in general. Kupper (1989) provided a more comprehensive definition, stating that "listening comprehension is an active and conscious process in which the listener constructs meaning by using cues from contextual information and from existing knowledge, while relying upon strategic resources to fulfil the task required" (p. 19).

\subsubsection{Listening Problems}

Listening problems are defined as the factors which could affect the listening comprehension of the listeners and cause problems for them during the listening process (Richards, 1983; Rost, 1990; Dunkel, 1991).

\subsection{Purpose of the Study}

This study intends to explore the following aims:

1). To discover the most frequent difficulties that Saudi EFL learners encounter while listening which affect their 
comprehension

2). To explore the effect of gender, academic level, years of studying English and the time spent listening by Saudi learners.

\subsection{Research Question}

The present study seeks to obtain information about the listening comprehension problems faced by Saudi postgraduate students studying in the University of Essex.

1) What listening comprehension problems do Saudi learners encounter most while listening to academic lectures/seminars?

2) Are there any differences between Saudi male and female learners in LC problems?

3) Do LC problems vary according to learners' academic levels?

4) Are there fewer LC problems depending on how long a student has been studying English?

5) Are there fewer LC problems depending on how much time a learner spends listening to English?

\section{Literature Review}

\subsection{Listening Comprehension Problems}

Listening comprehension is a complex process and there are various reasons influencing the comprehension in the process. Underwood (1989) provided seven possible reasons for problems with efficient listening comprehension: first, the speed of delivery of the text; second, listeners will not be able to have words repeated at all times; third, listeners have limited vocabulary; fourth, listeners could fail to identify the signs of the spoken language; fifth, the listener has a lack of context; sixth, the listeners may not understand when they hear something in their second language; and seventh, some learners take into account certain learning habits and they concentrate on them such as a wish to understand every word they hear. Furthermore, Yagang (1994) indicated that listening problems are related to four factors: the message, the speaker, the listener, and the physical setting.

Hasan (2000) indicated that unfamiliar words, difficult grammatical structures, and the length of the spoken passages are the most important factors that cause problems for learners' listening comprehension. He continued by highlighting clarity, lack of interest, and the demand for complete answers to listening comprehension questions as the most serious difficulties faced by students. Teng (2002) indicated that there are two types of factors which could affect listening comprehension: the first is the internal factor, which indicates the listener themselves, and the second is the external factor which represents aspects outside of the listener, for example the speaker, stimulus and context. Chen (2002) conducted a study on university students with LC problems. The study discovered five problems as the most frequent issues faced by learners. The first problem is that the learners focused on figuring out the meaning of part of the listening content and missed the other part. Second, students were unable to unpick streams of speech. Third, the learners did not recognize words they know. Fourth, they were not certain regarding key ideas within the text. Finally, they were unable to form a mental representation from the words they heard.

Graham (2006) stated that there are some other factors that increase learners' listening comprehension problems, for example restricted vocabulary, poor grammar, and misinterpretations about listening tasks. Rost (2011) provided four factors affecting LC which include the medium of the input, the nature of the input, the nature of the assessment task, and individual listener factors. Bloomfield et al. (2010) and Walker (2014) expressed that one of the serious problems of listening comprehension is related to the pronunciation of words, which is often different from the way they appear in print.

Finally, from the literature provided in this paper, it appears that listening comprehension is problematic for many FL learners. Researchers attribute this to factors that relate to characteristics of the listener, text, task, and process (Rubin, 1994). These studies have highlighted many factors that hinder learners' LC. Some of them are related to linguistic features of language and the content of listening text, while others are related the listener, the speaker and also the physical situation at the time of listening.

\section{Methods}

\subsection{Subjects}

The participants of the study were forty Saudi male and female postgraduate students from different departments of the University of Essex, UK. They were selected randomly, subject to willingness to participate in the current study. All of the Saudi students who participated in the present study were holders of the Saudi government scholarship to study in the University of Essex, UK. 
All participants had passed IELTS proficiency test between 2007 and 2011. Their average listening score in IELTS was $5.54(\mathrm{MIN}=4, \mathrm{MAX}=7, \mathrm{SD}=.75$ ) and the average overall score was 5.83 ( $\mathrm{MIN}=5, \mathrm{MAX}=7, \mathrm{SD}=.56$ ). The proficiency level of the participants in English communication skills ranged from bad to excellent according to their own self-assessments of these skills. The self-assessments of the participants indicated that the proficiency level of the Saudi students in listening was not bad; however, it ranged between satisfactory and good in their self-assessments of the four communication skills of English. The details of self-reported assessment of the students in the communication skills of English are given in Table 2.

Table 1. Subjects

\begin{tabular}{lllll}
\hline & & Level & & Total \\
& & MA & PhD & \\
\hline Gender & Female & 8 & 8 & 16 \\
& Male & 16 & 8 & 24 \\
Total & & 24 & 16 & 40 \\
\hline
\end{tabular}

Table 2. The self-reported proficiency level of the students in English communication skills

\begin{tabular}{cllll}
\hline Category & Writing & Reading & Listening & Speaking \\
\hline bad & 1 & 1 & 2 & 0 \\
satisfactory & 5 & 6 & 13 & 6 \\
good & 26 & 26 & 15 & 19 \\
excellent & 8 & 7 & 10 & 15 \\
Total & 40 & 40 & 40 & 40 \\
\hline
\end{tabular}

\subsection{Instruments}

The instrument that was used for collecting data was a questionnaire. The researcher designed the questionnaire items carefully on the basis of several previous studies (e.g., Boyle, 1984; Samules, 1984; Hwang, 2003; Underwood, 1989) in order to suit the population of the study and to provide the required information that could help him to answer the RQs reported in the current study.

The questionnaire designed for this study was divided into three main sections. These were labelled A, B and C and contained a total of seventeen questions. Section (A) was related to the personal background of the participants in order to obtain demographic information such as age, gender, major and academic level. Section (B) was related to English background and the experiences of the participants to answer the RQs that investigate the correlation between these experiences and the participants' LC problems such as their English proficiency, years spent studying English, and their listening experiences such as hours and methods. Moreover, the questionnaire contained a list of thirteen items. The answers to this question are recorded on a five-point Likert scale which consisted of five choices: 1 never; 2 rarely; 3 sometimes; 4 often; 5 always.

\subsection{Data Collection Procedure}

The present study was conducted on Saudi postgraduate students who were studying in the University of Essex by using a questionnaire. The researcher started distributing the questionnaires individually for all the participants who agreed to take part in the study. This process took place in different locations both inside and outside the University, and it took about two weeks for the questionnaires to be answered fully and then returned to the researcher.

\subsection{Data Analysis Procedure}

The study adopted quantitative research. Therefore, it was analysed in a quantitative manner by using the SPSS programme, version 19 to answer the research questions. The most and least frequent difficulties in listening comprehension are determined for each listening situation asked about based on the frequencies of the learners who experienced the difficulties. The comparisons between MA and $\mathrm{PhD}$ students and male and female students will be carried out using the Mann -Whitney test. Furthermore, the Wilcoxon test will be used to compare the two listening situations.

The Spearman rho test will be applied to measure the correlation between the frequency of listening comprehension problems and the given variables, which are the time spent studying English and the time spent listening to English. Finally, a regression analysis will be applied to determine which of these variables has the strongest effect on the LC of the Saudi students in each listening situation. For non-significant results, only $p$ 
values will be given. Figures and tables will be used to describe the data.

\section{Results and Discussion}

In this section, the data will be presented, analysed and discussed. The research questions will be presented one by one, and each question will be answered based on the findings of the study which are relevant to it.

\section{1) What listening comprehension problems do Saudi learners encounter most and least while listening to academic lectures/seminars?}

The LC problems Saudi learners encounter least and most were clear according to their answers in the questionnaire and are illustrated in Figure 2.

\section{FREQUENCY OF LC PROBLEMS}

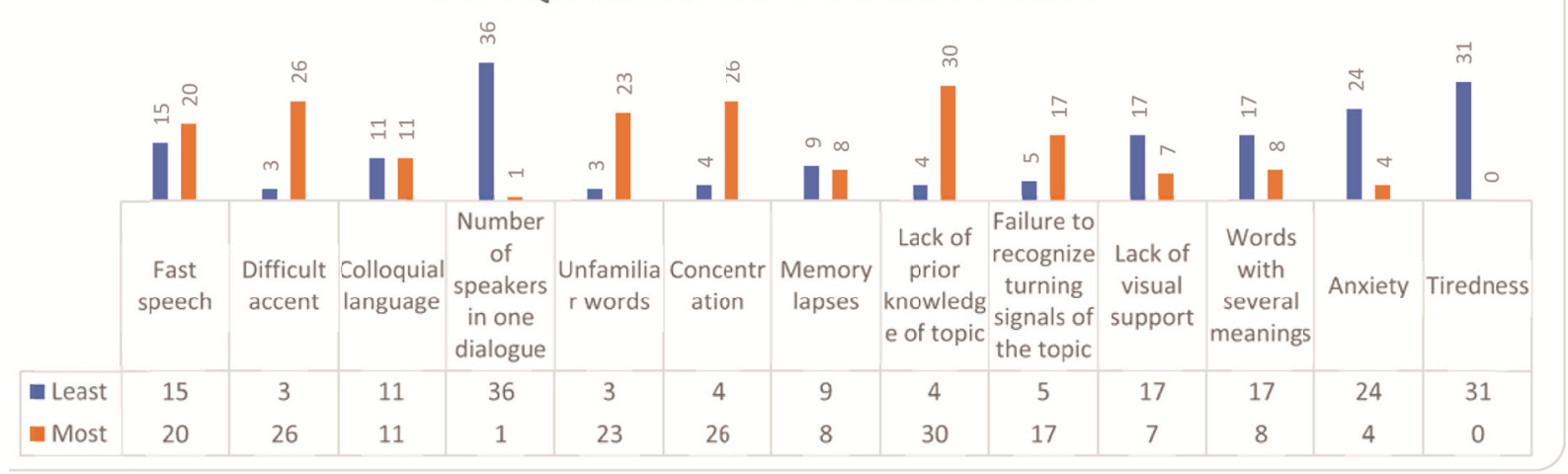

Figure 2. Frequency of LC problems

Figure 2 shows the least and the most frequent LC problems clearly as they were highlighted by the Saudi students. However, the focus of the study is the most frequent LC problems. It seems from the responses of the students that a lack of prior knowledge of the listening topic came first as three quarters of the students found this to be the most challenging aspect followed by concentration and a difficult accent, with 26 students considering these to be the second most frequent LC problems. The use of unfamiliar words and fast speech were the third most problematic aspects, being mentioned by 23 and 20 students respectively.

The failure to recognize the turning points from one point to another point in the topic came within the list of most frequent problems faced by the Saudi students while listening in academic settings, whether lectures or seminars, with agreement from 17 students. All these results concur with the views of several researchers who referred to these problems in their investigations (e.g., Anderson \& Lynch, 1988; Underwood, 1989; Boyle, 1984) and they indicated that these problems are considered as one of the clusters of the most serious problems influencing LC among EFL learners.

The results of the study are consistent with a number of outcomes from empirical studies provided by DeFilipps (1980), Goh (1998) and Laviosa (1991) cited in Hwang (2003) in her doctoral project regarding the most frequently problems faced by Saudi students. In their investigative studies, these authors indicated that difficult accents, unfamiliar words, fast speed, and difficulty regarding concentration are considered the most frequent LC problems faced by the learners. This supports the results of the present study regarding these problems with LC, which were discovered according to the responses of the participants in the questionnaire.

\section{2) Are there any differences between the Saudi male and female learners in LC problems?}

To answer this question, we applied the Mann-Whitney test to the responses of the Saudi students in the questionnaire to check whether there are any differences between the Saudi male and female students. However, the results of the Mann-Whitney test demonstrated that there is no significant $((p>.05)$ difference between the genders and the LC problems and that was clear through the responses of the Saudi students to the questionnaire's questions related to LC problems in both listening situations, which were listening to academic lectures or seminars and talking with native speakers in casual conversations. This is shown in the two figures below. Consequently, this result is consistent with the outcomes of many studies which have researched these LC problems among EFL learners.

Such studies include Bacon (1992), who conducted his study on University students of Spanish and his results 
support the present study by showing there is no significant difference between males and females in LC. Moreover, Karimman (2001) conducted his study in the same context on Iranian EFL learners to study the effects of gender on LC. However, his study also demonstrated that there is no significant difference between the genders (i.e. males/females) and the LC. The non-significant difference between the Saudi male and female students in LC problems can be clearly seen in the two situations in the two figures below.

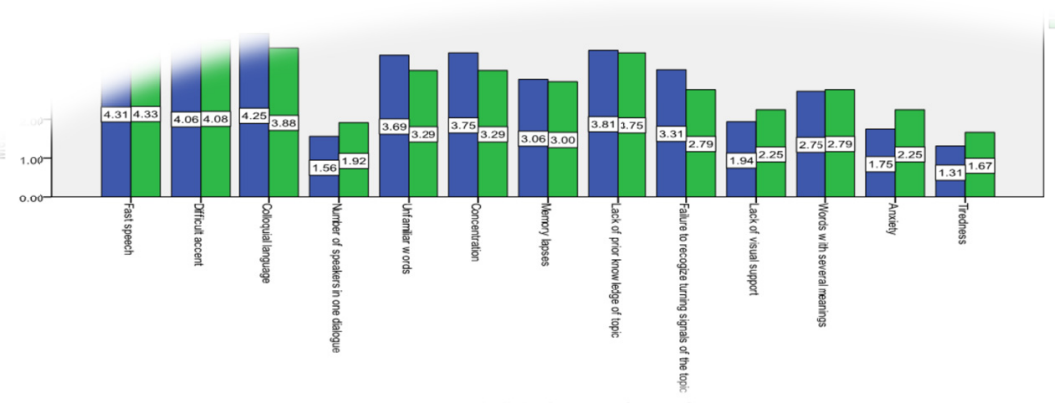

Figure 3. The difference in LC problems between the Saudi male and female students in casual speech

\section{3) Do LC problems vary according to learners' academic levels?}

To answer this question, the Mann-Whitney test was again applied on the responses of the Saudi students. The results of the test in the first listening situation, which is academic lectures or seminars, showed that there is a significant difference $(\mathrm{p}<.05)$ between the MA and PhD students in relation to nine LC problems as they are given in the table. Moreover, The $\mathrm{z}$ and $\mathrm{p}$ values are also shown in Table 4 through the test results. The same test applied was to the answers of the students in the questionnaire, which indicated that the MA and PhD Saudi students differ from each other in various factors included difficult accents, the number of the speakers in the dialogue, memory problems and visual support.

The responses of the MA and PhD students are represented in Figure 5. Finally, we need to indicate that the answers to this question revealed a negative correlation between the academic level of the learners and the LC problems and that was clear through the responses of the participants to the questionnaire as LC problems of the $\mathrm{PhD}$ students were fewer than the LC problems of the MA students. This means that when the academic level is higher there are fewer LC problems.

Table 3. The difference between MA and PhD students in lectures or seminars

\begin{tabular}{lll}
\hline Problems & $\mathbf{Z}$ & $\begin{array}{l}\text { Asymp. Sig. } \\
\text { (2-tailed) }\end{array}$ \\
\hline Fast speech & -3.167 & 0.002 \\
Colloquial speech & -2.356 & 0.018 \\
Unfamiliar words & -2.034 & 0.042 \\
Concentration & -2.027 & 0.043 \\
Lack of prior knowledge of listening topic & -2.298 & 0.022 \\
Failure to recognize the turning signals of the topic & -2.85 & 0.004 \\
Words with several meanings & -2.419 & 0.016 \\
Anxiety & -3.545 & 0.000 \\
Tiredness & -2.733 & 0.006 \\
\hline
\end{tabular}




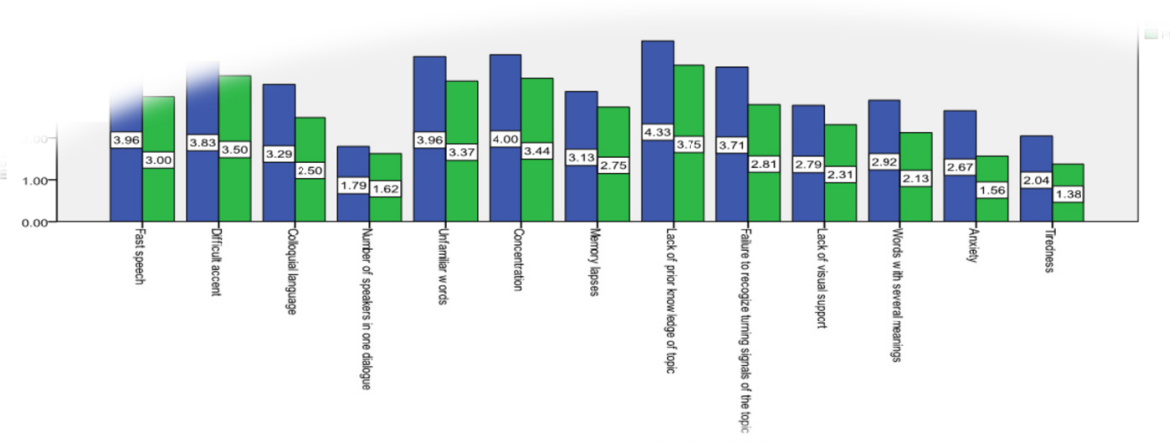

Figure 4. The difference between MA and PhD students in LC problems in academic lectures or seminar

Table 4. The significant difference in LC problems between MA and PhD students in casual conversation

\begin{tabular}{|c|c|c|c|c|}
\hline Problems & $\begin{array}{l}\text { Fast } \\
\text { speech }\end{array}$ & Unfamiliar words & $\begin{array}{l}\text { Memory } \\
\text { lapses }\end{array}$ & $\begin{array}{l}\text { Words with } \\
\text { several meanings }\end{array}$ \\
\hline Mann-Whitney U & 109.00 & 120.00 & 110.00 & 117.50 \\
\hline Wilcoxon W & 245.00 & 256.00 & 246.00 & 253.50 \\
\hline $\mathrm{Z}$ & -2.51 & -2.09 & -2.49 & -2.24 \\
\hline Asymp. Sig. (2-tailed) & .012 & .036 & .013 & .025 \\
\hline Exact Sig. [2*(1-tailed Sig.)] & $.021^{\mathrm{a}}$ & $.048^{\mathrm{a}}$ & $.023^{\mathrm{a}}$ & $.039^{\mathrm{a}}$ \\
\hline
\end{tabular}

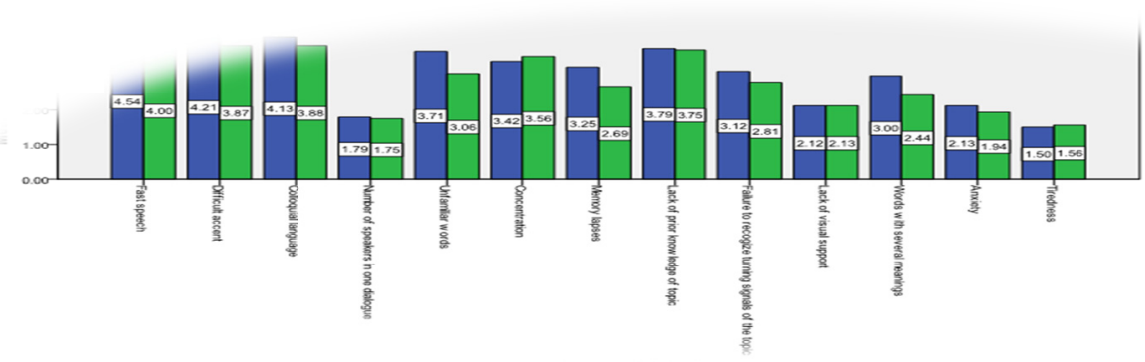

Figure 5. The difference between MA and $\mathrm{PhD}$ students in LC problems in casual conversation

\section{4) Are there fewer LC problems depending on how long a student has been studying English?}

To answer this question, the researcher applied a correlation test on the data provided by the respondents in the questionnaire regarding LC problems in academic settings to discover whether there are any negative correlations between the LC problems and the length of time spent by the Saudi students on studying English. The results of the test showed that the period of the time spent by the Saudi students studying English $(M=8.45$ years, $\mathrm{MIN}=1, \mathrm{MAX}=18, \mathrm{SD}=4.99$ ) has various correlations. A negative correlation clearly appeared with $\mathrm{LC}$ problems such as the fast speech of the speakers and the difficult accent of the speaker.

The correlation test results showed that some LC problems have a moderate negative correlation with the time spent by the Saudi students studying English and LC problems they face such as problems related to concentration and the problems of memory. Additionally, the correlation test indicated that there is a strong negative correlation with the problem of fast speech, which has been considered by many researchers in the listening comprehension area as the most serious problem faced by L2 learners (e.g., Flower and Miller, 1996; Goh, 1997; Underwood, 1989). The correlation test, which measures the correlation between the LC problems and the time spent studying English in academic settings, lectures or seminars, can be seen clearly in Table 5 and later in Figure 6 Moreover, casual conversation test demonstrated that there is a negative correlation between the LC problems that the Saudi students encounter in casual conversation and the time they spend $(M=8.45$ years, $\mathrm{MIN}=1$ years, $\mathrm{MAX}=18$ years, $\mathrm{SD}=4.99$ ) on studying English, which are the problems related to the listener. These are shown in the Table 5 . 
Table 5. The correlation between LC problems and period of studying English

\begin{tabular}{lll}
\hline Problems & $\begin{array}{l}\text { Correlation } \\
\text { Coefficient }\end{array}$ & $\begin{array}{l}\text { Sig. } \\
\text { (2-tailed) }\end{array}$ \\
\hline Fast speech & -.600 & 0.000 \\
Different accent & -.520 & 0.001 \\
Colloquial speech & -.517 & 0.001 \\
Number of speakers in one dialogue & -0.103 & 0.527 \\
Unfamiliar words & -.452 & 0.003 \\
Concentration & -.482 & 0.002 \\
Memory & -.346 & 0.029 \\
Lack of prior knowledge of the listening topic & -.568 & 0.000 \\
Failure to recognize turning signals of the topic & -.521 & 0.001 \\
Visual support & -.466 & 0.002 \\
Words with several meanings & -.591 & 0.000 \\
Anxiety & -.524 & 0.001 \\
Tiredness & -.367 & 0.02 \\
\hline
\end{tabular}

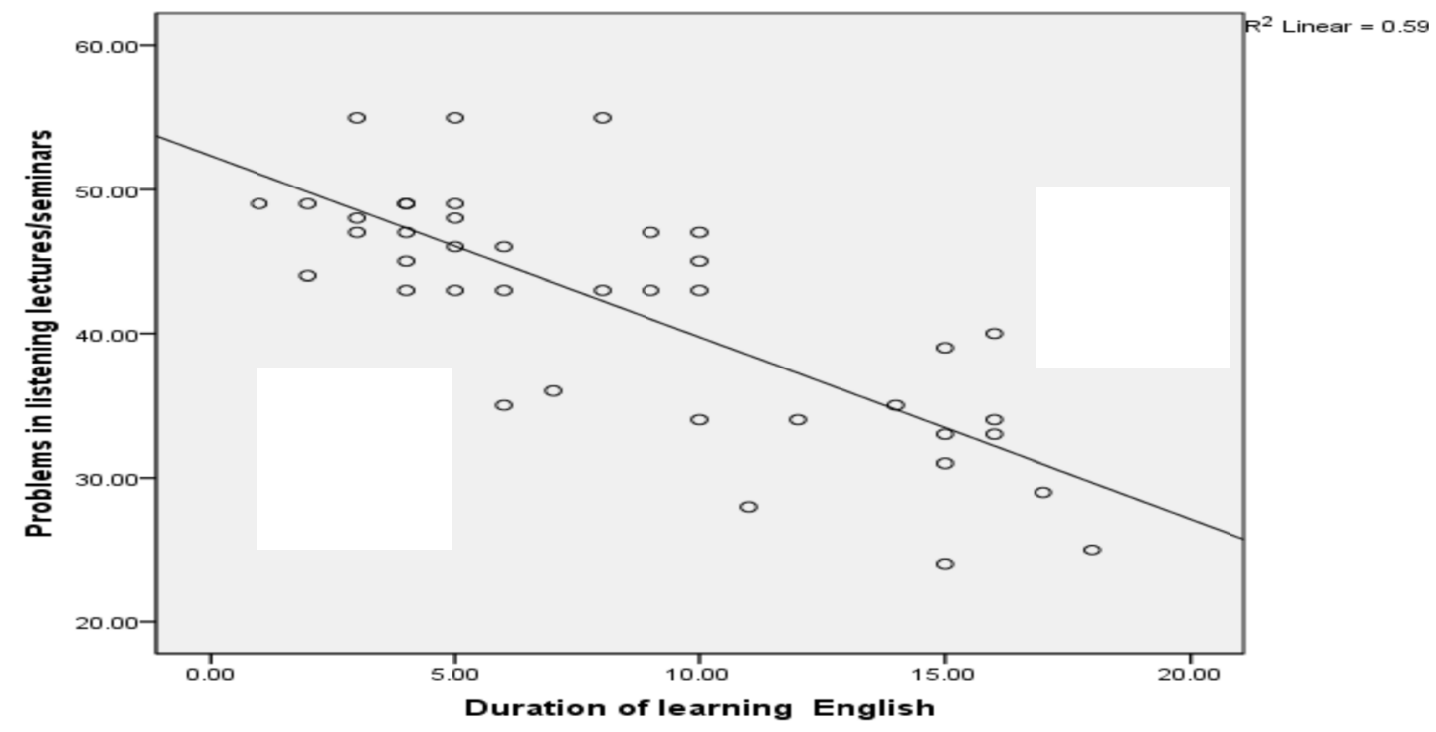

Figure 6. The correlation between LC problems and period of studying English

Table 6. The correlation between LC problems and length of study English in casual conversation

\begin{tabular}{lll}
\hline Problems & $\begin{array}{l}\text { Correlation } \\
\text { Coefficient }\end{array}$ & Sig. (2-tailed) \\
\hline Fast speech & -.291 & .069 \\
Difficult accent & -.268 & .095 \\
Colloquial language & -.110 & .499 \\
Unfamiliar words & -.120 & .462 \\
Concentration & -.035 & .828 \\
Memory lapses & -.532 & .000 \\
Lack of prior knowledge of topic & .005 & .975 \\
Failure to recognize turning signals of the topic & -.321 & .043 \\
Lack of visual support & -.093 & .566 \\
Words with several meanings & -.502 & .001 \\
Anxiety & -.256 & .111 \\
Tiredness & -.091 & .578 \\
\hline
\end{tabular}

\section{5) Are there fewer LC problems depending on how much time a learner spends listening to English?}

The Saudi students have many opportunities to listen to English. They can listen to English in seminars, classrooms, conversations, radio, TV and other ways. The Saudi students mentioned the number of hours they 
spend in listening to English, whether inside the classroom when they attend their lectures or seminars or outside classrooms when they listen to radio, TV or have conversations with people. All of the listening hours mentioned by the Saudi students in their responses in the questionnaire have been combined.

Therefore, to answer this question, Spearman's correlation test was applied to identify the correlation between the length of time spent by MA students $(\mathrm{M}=36.13$ hours, $\mathrm{MIN}=14, \mathrm{MAX}=89, \mathrm{SD}=17.50)$ and the time spent by $\mathrm{PhD}$ students $(\mathrm{M}=27.81$ hours, $\mathrm{MIN}=6, \mathrm{MAX}=49, \mathrm{SD}=12.60)$ listening to English and the $\mathrm{LC}$ problems related to academic lectures or seminars. The test showed that there is no significant correlation ( $p>.05)$ between the overall time spent listening to English by the MA and PhD Saudi students on a weekly basis and the problems related to their LC in academic lectures or seminars as one of the two listening situations.

However, this finding is inconsistent with many researchers who have considered that the practice of listening could be useful in reducing the learners' problems with LC. The result was not highly different in this type of listening situation compared to the previous listening situation (i.e. academic lectures or seminars) as the results of the test showed that there is only a moderate negative correlation (Correlation Coefficient $(r)=-.334$, sig $=.03$ ) between the LC problems of Saudi students in casual conversation and the overall weekly listening hours of the Saudi students. The moderate negative correlation was only with the problem of colloquial language (sig=.03) faced by learners in this setting. Additionally, the correlation between other problems related to listening comprehension and overall listening hours of English spent by the Saudi students was non-significant $(\mathrm{p}>.05)$. The test results can be clearly seen in the Table 6 and Figure 7.

Table 7. Correlation between the time spent listening to English and LC problems related to lectures/seminars

\begin{tabular}{lll}
\hline Problems & $\begin{array}{l}\text { Correlation } \\
\text { Coefficient }\end{array}$ & Sig. (2-tailed) \\
\hline Fast speech & .032 & .845 \\
Difficult accent & -.068 & .676 \\
Colloquial language & .135 & .407 \\
Number of speakers in one dialogue & .016 & .922 \\
Unfamiliar words & -.281 & .079 \\
Concentration & -.237 & .141 \\
Memory lapses & -.304 & .057 \\
Lack of prior knowledge of topic & .047 & .771 \\
Failure to recognize turning signals of the topic & .112 & .493 \\
Lack of visual support & .178 & .273 \\
Words with several meanings & .098 & .548 \\
Anxiety & -.072 & .658 \\
Tiredness & -.146 & .369 \\
\hline
\end{tabular}

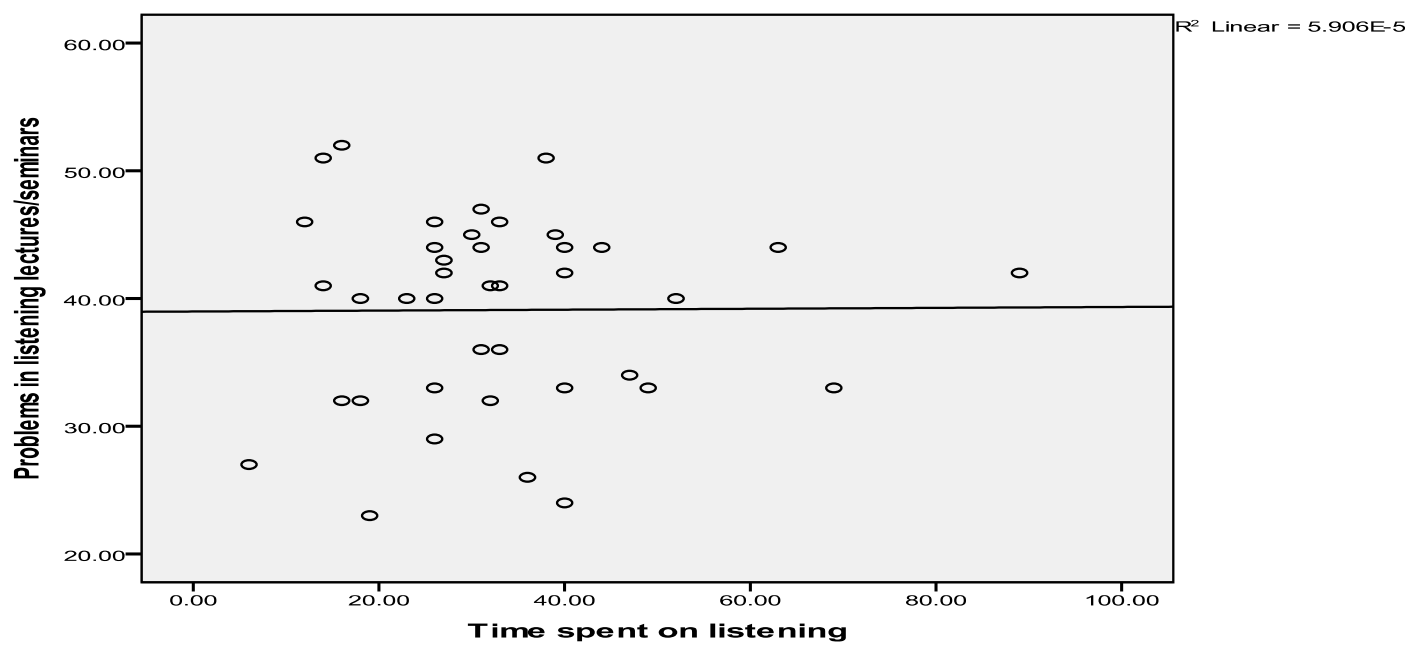

Figure 7. The correlation between the time spent listening to English and LC problems in academic lectures or seminars 


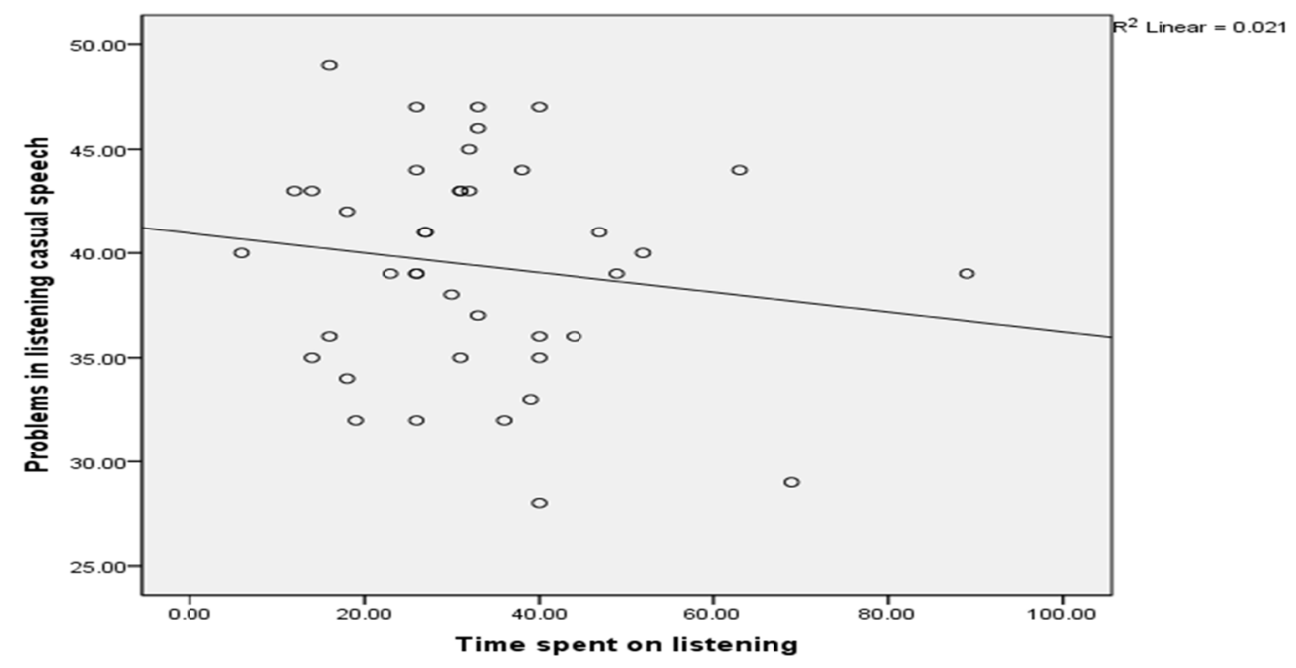

Figure 8. The correlation between the time spent listening to English and LC problems in academic lectures or seminars

Table 8. The correlation between the time spent listening to English and LC problems in academic lectures or seminars

\begin{tabular}{lll}
\hline Problems & $\begin{array}{l}\text { Correlation } \\
\text { Coefficient }\end{array}$ & $\begin{array}{l}\text { Sig. } \\
\text { (2-tailed) }\end{array}$ \\
\hline Fast speech & .027 & .870 \\
Difficult accent & -.165 & .308 \\
Colloquial language & -.344 & .030 \\
Number of speakers in one dialogue & .050 & .762 \\
Unfamiliar words & -.195 & .227 \\
Concentration & -.064 & .693 \\
Memory lapses & -.125 & .443 \\
Lack of prior knowledge of topic & -.231 & .152 \\
Failure to recognize turning signals of the topic & .007 & .964 \\
Lack of visual support & -.084 & .608 \\
Words with several meanings & .010 & .949 \\
Anxiety & .088 & .591 \\
Tiredness & .165 & .309 \\
\hline
\end{tabular}

After identifying the negative correlations between the LC problems and the variables reported above, regression analysis was applied in order to discover which of these two variables, the length of studying English or the length of time spent listening to English, could strongly influence the LC of the Saudi students.

The regression analysis was applied to the overall LC problems of the Saudi students in both listening situations, academic lectures or seminars and casual speech. The resultant data showed that only the duration of studying English has a significant effect on the listening comprehension of the Saudi learners of English, while the length of time the Saudi students spend on listening to English had no significant effect on listening comprehension of the Saudi students. Consequently, it can be concluded that the level of EFL among Saudi student is affected to a greater extent by the years they spend studying English than the time they spend on listening to English. The results of the regression analysis of the two listening situations are given in the following tables. 
Table 9. Regression analysis for listening in academic lectures or seminars

\begin{tabular}{lllllll}
\hline \multicolumn{1}{l}{ Model } & \multicolumn{2}{l}{$\begin{array}{l}\text { Unstandardized } \\
\text { Coefficients }\end{array}$} & $\begin{array}{l}\text { Standardized } \\
\text { Coefficients } \\
\text { Beta }\end{array}$ & t & & Sig. \\
& & B & Std. Error & & & \\
\hline $\mathbf{1} \quad$ (Constant) & 52.424 & 2.905 & & 18.048 & .000 \\
& Duration of studying English & -1.171 & .161 & -.788 & -7.257 & $\mathbf{. 0 0 0}$ \\
& Listening to English & -.071 & .049 & -.153 & -1.434 & .160 \\
\hline
\end{tabular}

a. Dependent Variable: Listening in lectures or academic seminars

Table 10. Regression analysis for listening in casual conversation

\begin{tabular}{|c|c|c|c|c|c|c|}
\hline \multicolumn{2}{|c|}{ Model } & \multicolumn{2}{|c|}{ Unstandardized Coefficients } & \multirow{2}{*}{$\begin{array}{l}\text { Standardized } \\
\text { Coefficients } \\
\text { Beta }\end{array}$} & \multirow[t]{2}{*}{$\mathbf{t}$} & \multirow[t]{2}{*}{ Sig. } \\
\hline & & $\mathrm{B}$ & Std. Error & & & \\
\hline \multirow[t]{3}{*}{2} & (Constant) & 47.905 & 2.891 & & 16.569 & .000 \\
\hline & Duration of learning English & -.356 & .161 & -.342 & -2.215 & .033 \\
\hline & Listening to English & -.064 & .049 & -.197 & -1.303 & .201 \\
\hline
\end{tabular}

\section{Conclusion and Recommendations}

This study was conducted to explore listening comprehension problems among Saudis in addition to researching several correlations with Saudi learners' comprehension problems. The study was conducted by adopting a questionnaire. The findings demonstrate that that lack of prior knowledge regarding the listening topic came first followed by concentration, while a difficult accent come first in terms of LC difficulty. While the use of unfamiliar words, fast speech came as second place reasons as in difficulty LC for the students. Moreover, the study indicated that there is no significant correlation between males and females in the issue of listening comprehension. The study also confirmed that listening comprehension is affected at the academic level; when it goes up, the LC problems go down and the opposite is true. Finally, the study showed that the only significant correlation with listening comprehension was the time spent learning English by the EFL learners because when the learners spend more time learning English, their problems with LC will be reduced.

\subsection{Recommendations}

Based on the study findings, the researcher makes some recommendations for future researchers in this field.

- It would be better if investigations are conducted based on the strategies that could contribute to reducing the listening comprehension problems.

- It would be useful for the researchers if they employed more research methods in future studies including classroom observations, listening comprehension tests and think-aloud protocols in order to increase the credibility and validity of their results.

- It would be better if the researchers explored the influence of more LC problems.

- It is hoped that more studies will be conducted with large samples of learners in order to be generalized.

\section{Acknowledgement}

I thank Allah who inspired me to start this paper, and to my lovely small family who supported me to finish this paper, my wife Amal Almjlad and my sweet children, Abdulaziz, Ghadah and Aseel who always bring me happiness.

\section{References}

Bacon, S. M. (1992). The relationship between gender, comprehension, processing strategies, cognitive and affective response in foreign language listening. The Modern Language Journal, 76(2), 160-177. https://doi.org/10.1111/j.1540-4781.1992.tb01096.x

Boyle, J. P. (1984). Factors affecting listening comprehension. ELT Journal, 38(1), 34-38. https://doi.org/10.1093/elt/38.1.34

Chen, S. W. (2002). Problems in listening comprehension for learners of EFL. Studies in English Language and Literature, 10, 57-70.

Conaway, M. S. (1982). Listening: Learning tool and retention agent. In A. S. Algier \& K. W. Algier (Eds.), 
Improving reading and study skills (pp. 51-63). San Francisco: Jossey-Bass.

Denzin, N. K., \& Lincoln, Y. S. (2000). Introduction: The discipline and practice of qualitative research. In N. K. Denzin \& Y. S. Lincoln (Eds.), Handbook of qualitative research (2nd ed.) (pp. 1-28). Thousand Oaks, CA: SAGA Publication.

Dunkel, P. (1986). Developing listening fluency in L2: Theoretical principles and pedagogical considerations. The Modern Language Journal, 70(2), 99-106. https://doi.org/10.1111/j.1540-4781.1986.tb05250.x

Dunkel, P. (1991). Listening in the native and second/foreign language: Toward an integration of research and practice. TESOL Quarterly, 25, 431-457. https://doi.org/10.2307/3586979

Feyten, C. M. (1991). The power of listening ability: An overlooked dimension in language acquisition. Modern Language Journal, 75(2), 173-180. https://doi.org/10.1111/j.1540-4781.1991.tb05348.x

Hasan, A. (2000). Learners' perceptions of listening comprehension problems. Language, Culture and Curriculum, 13(2), 137-153. https://doi.org/10.1080/07908310008666595

Hwang, M. (2003). Listening comprehension problems and strategy use by Secondary Learners of English (EF) in Korea. Unpublished doctoral thesis. University of Essex.

Kariminian, A. (2001). The effect of speakers' and listeners' gender on listening comprehension. Unpublished master's thesis. Shiraz Azad University, Shiraz.

Kemp, J. (2010). The listening log: Motivating autonomous learning. ELT Journal, 64(4), 385-395. https://doi.org/10.1093/elt/ccp099

Krashen, S. D. (1985). The input hypothesis: Issues and implications. New York: Longman

Lundsteen, S. (1971). Listening: Its impact on reading and the other language arts. Urbana, IL: National Council of Teachers of English.

Morley. (2001). Aural comprehension practice instructions: Principles and practices. In Celce-Murcia, Teaching English as a second or foreign language (pp. 69-85).

O’Malley, J. M., Chamot, A. U., \& Kupper, L. (1989). Listening comprehension strategies in second language acquisition. Applied Linguistics, 10, 418-437. https://doi.org/10.1093/applin/10.4.418

Patton, M. Q. (1990). Qualitative evaluation and research methods (2nd ed.). Newbury, CA: Sage.

Purdy, M. (1997). What is listening? In M. Purdy \& D. Borisoff (Eds.), Listening in everyday life: A personal and professional approach (2nd ed.) (pp. 1-20). Lanham, MD: University Press of America.

Richards, J. C. (1983). Listening comprehension: Approach, design, procedure. TESOL Quarterly, 17(2), 219-239. https://doi.org/10.2307/3586651

Rost, M. (1990). Listening in Language Learning. London: Longman.

Rost, M. (2001). Teaching and researching listening. London: Longman.

Samuels, S. (1984). Factors Influencing Listening: Inside and Outside the Head, 23(3), 183-189. Retrieved from EBSCOhost database.

Teng, H. C. (2002). An investigation of EFL listening difficulties for Taiwanese students. Selected Papers from the Eleventh International Symposium on English Teaching/Fourth Pan-Asian Conference (pp. 526-533). Taipei, Taiwan: Crane.

Underwood, M. (1989). Teaching listening. London: Longman.

Vandergrift, L. (1992). The comprehension strategies of second language (French) listeners. Unpublished $\mathrm{PhD}$ thesis, University of Alberta. (Source: Ann Arbor, MI: University Microfilms International, ACC NN77335).

Ward, J. (1990). Now hear this: Without listening, there is no communication. Communication World, 5(5), 12-15. Retrieved from EBSCOhost database.

Werner, E. K. (1975). A study of communication time. Unpublished master's thesis. University of Maryland.

Yagang, F. (1994) Listening: Problems and solutions. In T. Kral (Ed.), Teacher Development: Making the Right Moves. Washington, DC: English Language Programs Divisions, USIA. 


\section{Copyrights}

Copyright for this article is retained by the author(s), with first publication rights granted to the journal.

This is an open-access article distributed under the terms and conditions of the Creative Commons Attribution license (http://creativecommons.org/licenses/by/4.0/). 